\title{
Bimodal expressivity in dominant retinitis pigmentosa genetically linked to chromosome $19 q$
}

\author{
K Evans, M Al-Maghtheh, F W Fitzke, A T Moore, M Jay, C F Inglehearn, G B Arden, \\ A C Bird
}

\begin{abstract}
A clinical, psychophysical, and electrophysiologic study was undertaken of two autosomal dominant retinitis pigmentosa pedigrees with a genetic mutation assigned to chromosome 19q by linkage analysis. Members with the abnormal haplotype were either symptomatic with adolescent onset nyctalopia, restricted visual fields, and non-detectable electroretinographic responses by 30 years of age, or asymptomatic with normal fundus appearance and minimal or no psychophysical or electroretinographic abnormalities. There was no correlation in the severity in parents and their offspring. Pedigree analysis suggested that although the offspring of parents with the genetic mutation were at $50 \%$ risk of having the genetic defect, the risk of being symptomatic during a working lifetime was only $31 \%$. Such bimodal phenotypic expressivity in these particular pedigrees may be explained by a second, allelic genetic influence and may be a phenomenon unique to this genetic locus. Genetic counselling in families expressing this phenotype can only be based on haplotype analysis since clinical investigations, even in the most elderly, would not preclude the presence of the mutant gene.

(Br f Ophthalmol 1995; 79: 841-846)
\end{abstract}

Epidemiological studies of retinitis pigmentosa consistently report a frequency of one in 5000 of the general population suggesting that there are approximately 100000 retinitis pigmentosa sufferers in Europe and a similar number in the USA. ${ }^{1}$ A family history of retinitis pigmentosa can be demonstrated in approximately $50 \%$ of new cases, and all three mendelian inheritance patterns occur. Autosomal dominant inheritance accounts for approximately $17-25 \%$ of all cases ${ }^{1-3}$ and the condition has been found to be genetically heterogeneous. Over 60 different mutations in the rhodopsin gene on chromosome $3 \mathrm{q}^{4}$ and 18 peripherin/RDS gene mutations ${ }^{5}$ have been found in different autosomal dominant retinitis pigmentosa pedigrees. Five other loci for dominant retinitis pigmentosa genes have been identified on chromosomes $7 \mathrm{p},{ }^{6} 7 \mathrm{q},{ }^{7} 8 \mathrm{cen},{ }^{8} 17 \mathrm{p},{ }^{9}$ and $19 \mathrm{q}^{10}$ by genetic linkage analysis.

In addition to the genetic diversity seen in autosomal dominant retinitis pigmentosa, phenotypic variability is also well established. Differences in clinical presentation have been reported between different families. Differences between members of the same family, variable expressivity, is also a common characteristic of autosomal dominant disease. ${ }^{11}$ Here we report an extended clinical, psychophysical, and electrophysiological study of two families expressing a retinitis pigmentosa phenotype genetically linked to chromosome $19 \mathrm{q} .{ }^{10}$ Haplotype data have now allowed sound genetic diagnosis, making it possible to compare accurately the severity of disease in patients with that in their offspring. This has led to the identification of a large number of asymptomatic individuals carrying the disease gene suggesting an unusual polarity of phenotype in that those with the disease gene seem either to be severely afflicted or are asymptomatic with little psychophysical or electroretinographic abnormality, a phenotype unlike that reported in other retinitis pigmentosa genotypes.

\section{Patients and methods}

Some clinical details on these unrelated families have been reported previously (family 3 and 4 respectively). ${ }^{12}$ The former originates in south Wales and the latter from northeast England. Further clinical studies and linkage analysis have allowed the identification of eight symptomatic and eight disease haplotype carriers not included in the previous report. Autosomal dominant inheritance is evident with symptomatic individuals in each generation and male to male transmission. Asymptomatic patients were assigned as having the causative genetic mutation if they had the same haplotype as symptomatic individuals within a 20 centimorgan region of chromosome 19q. Family members with this haplotype have a $>98 \%$ probability of carrying the disease mutation. ${ }^{10}$ Thirty individuals were identified as having the abnormal gene and enrolled into the study. In family ' 3 ' this included five symptomatic individuals and four asymptomatic individuals with the disease haplotype. One of these asymptomatic patients, an obligate carrier, had a symptomatic child. In family ' 4 ', 13 symptomatic patients and eight asymptomatic individuals with the disease haplotype were examined (including three obligate carriers).

An extensive ophthalmic history was recorded including details of visual acuity loss and age of onset of nyctalopia. Full ophthalmic examination was undertaken which included assessment of visual acuity, examination of the anterior segment and fundus. To assess whether or not a systemic abnormality might segregate with ocular disease, a detailed general medical history and a brief physical examination were undertaken. 
A

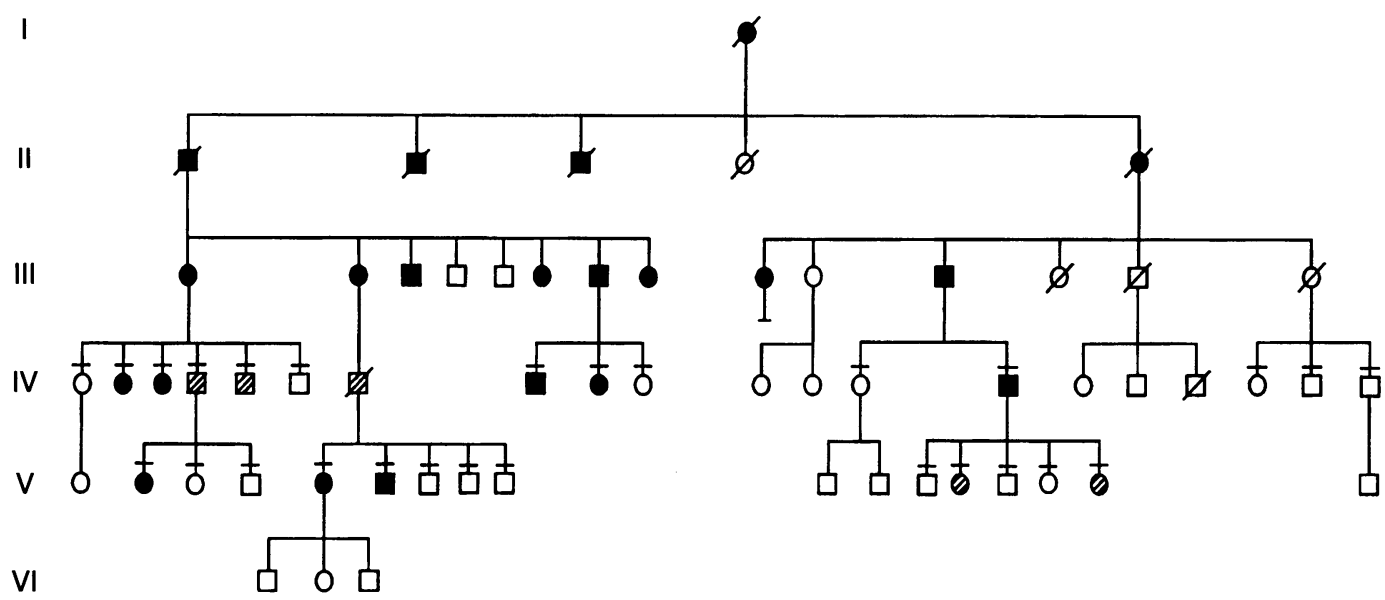

B

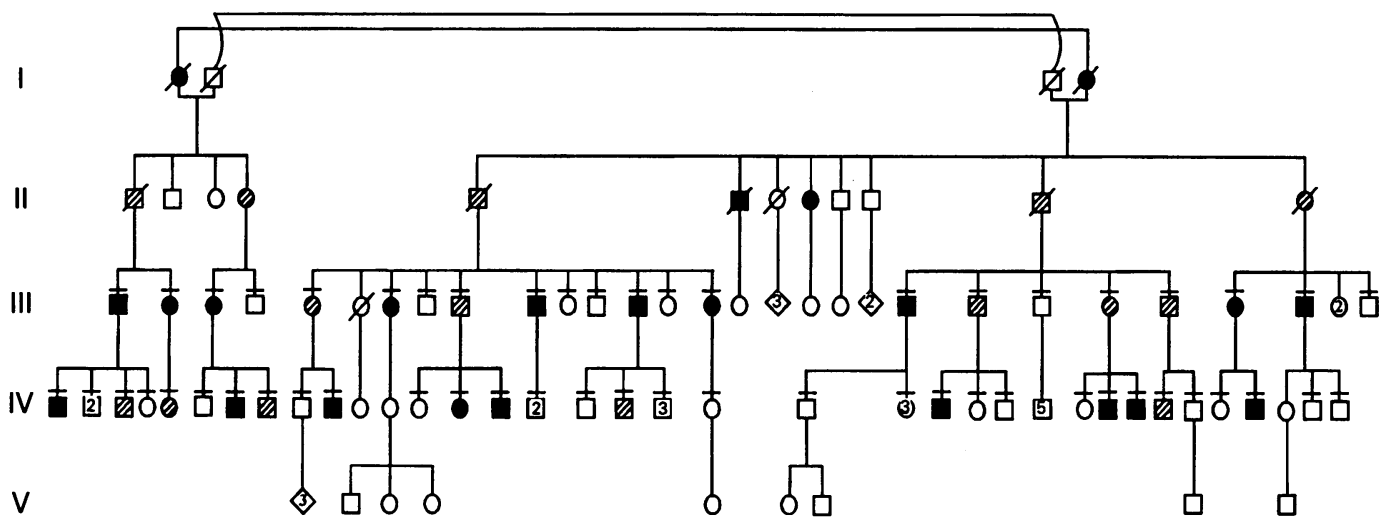

Figure 1 Pedigrees for families $3(A)$ and $4(B)$. Symptomatic male, $\bigcirc$ unaffected female, $\mathbb{1}$ disease-haplotype carrier. Bar above symbol identifies patients who underwent DNA examination.

For psychophysical studies pupils were dilated with $1 \%$ cyclopentolate hydrochloride and $2 \cdot 5 \%$ phenylephrine hydrochloride, and subjects dark adapted for 40 minutes. Dark adapted static perimetry was undertaken using a modified Humphrey automated perimeter (Allergan Humphrey, San Leandro, CA, USA). ${ }^{13-15}$ Cone and rod sensitivities were assessed using a standard Humphrey $30-2$ program with the background illumination turned off. Size 5 red and blue test stimuli were used. In each case the eye with the better visual acuity was tested. For dark adaptometry, prebleach thresholds were then determined at selected positions. Patients were exposed to bright white light for 2 minutes sufficient to bleach $95 \%$ of rhodopsin $(7.5 \mathrm{log}$ scotopic Tröland-second delivered over 45 seconds). Recovery of sensitivity with time was assessed with size 5 blue test stimuli. ${ }^{16-18}$

Selected subjects underwent electrophysiological investigation using a 'short-protocol' adapted from that recommended by the International Standard for Clinical Ophthalmology. 1920 Dark adapted electroretinography including blue flash ('run 7' to elicit rod isolated responses), red flash ('run 18', cone dominated responses), white flash ('run 20', mixed photoreceptor responses) and $30 \mathrm{~Hz}$ flicker ('run 31' cone isolated) responses were recorded. Electro-oculography was performed as previously described. ${ }^{21}$
The study was approved by the local ethics committee and informed consent was obtained from each subject enrolled into the study.

\section{Results}

Revised pedigrees are presented in Figures 1A and $1 \mathrm{~B}$. Linkage studies in both families identified seven individuals as recombinant over the entire $19 \mathrm{q}$ linked region. This prompted a reappraisal of their clinical status which had previously been based on ophthalmic history only. These examinations resulted in redesignation of disease status of two subjects in pedigree 3 (3-III-14 and 3-IV-20 as phenotypically normal) and five in pedigree 4 (4-III-7, 4-IV-1, and 4-IV-15 as phenotypically abnormal, $4-\mathrm{IV}-25$ and $4-\mathrm{IV}-46$ as normal). This and the identification of nine extra asymptomatic disease haplotype carriers accounts for differences from previously published family trees, more accurately reflecting segregation of the disease. ${ }^{12}$ Because information was based on historical data in some generations, segregation of disease status was examined in generations III-V only in pedigree 3 and II-IV only in pedigree 4 . This identified 57 symptomatic plus disease haplotype carriers and 63 unaffected individuals born to symptomatic or disease haplotype carrier parents. Approximately half $(48 \%)$ of at risk individuals had inherited the disease 
Table 1 Clinical details of 30 symptomatic and disease haplotype carrier patients

\begin{tabular}{|c|c|c|c|c|c|c|c|}
\hline \multirow[b]{2}{*}{ Patient } & \multirow{2}{*}{$\begin{array}{l}\text { Age } \\
\text { (years) }\end{array}$} & \multirow{2}{*}{$\begin{array}{l}\text { Genetic } \\
\text { status }\end{array}$} & \multirow{2}{*}{$\begin{array}{l}\text { Nyctalopia } \\
\text { age at onset } \\
\text { (years) }\end{array}$} & \multicolumn{2}{|c|}{ Visual acuity } & \multirow{2}{*}{$\begin{array}{l}\text { Lens } \\
\text { opacities }\end{array}$} & \multirow[b]{2}{*}{ Fundal examination } \\
\hline & & & & Right & Left & & \\
\hline $\begin{array}{l}\text { 3-IV-2 } \\
\text { 3-IV-15 } \\
3-V-2 \\
3-V-5 \\
3-V-6 \\
4-I I I-1 \\
4-I I I-2 \\
4-I I I-3 \\
4-I I I-13 \\
\text { 4-III-15 } \\
\text { 4-III-29 } \\
\text { 4-IV-1 } \\
4-I V-8 \\
4-I V-11 \\
4-I V-29 \\
4-I V-38 \\
4-I V-39 \\
4-I V-43 \\
\text { 3-IV-5 } \\
\text { 3-IV-6 } \\
\text { 3-V-13 } \\
\text { 3-V-16 } \\
4-I I I-5 \\
4-I I I-25 \\
4-I I I-27 \\
4-I I I-28 \\
4-I V-6 \\
4-I V-9 \\
4-I V-20 \\
4-I V-40\end{array}$ & $\begin{array}{l}62 \\
61 \\
24 \\
57 \\
52 \\
61 \\
50 \\
54 \\
60 \\
52 \\
48 \\
26 \\
25 \\
45 \\
25 \\
33 \\
30 \\
28 \\
57 \\
55 \\
33 \\
24 \\
75 \\
49 \\
57 \\
55 \\
28 \\
26 \\
30 \\
26\end{array}$ & $\begin{array}{l}\text { s } \\
\text { s } \\
\text { s } \\
\text { s } \\
\text { s } \\
\text { s } \\
\text { s } \\
\text { s } \\
\text { s } \\
\text { s } \\
\text { s } \\
\text { s } \\
\text { s } \\
\text { s } \\
\text { s } \\
\text { s } \\
\text { s } \\
\text { s } \\
d \\
d \\
d \\
d \\
d \\
d \\
d \\
d \\
d \\
d \\
d \\
d\end{array}$ & $\begin{array}{r}6 \\
10 \\
11 \\
15 \\
9 \\
8 \\
9 \\
18 \\
10 \\
5 \\
4 \\
\text { No } \\
5 \\
5 \\
8 \\
13 \\
10 \\
15 \\
\text { No } \\
\text { No } \\
\text { No } \\
\text { No } \\
\text { No } \\
\text { No } \\
\text { No } \\
\text { No } \\
\text { No } \\
\text { No } \\
\text { No } \\
\text { No }\end{array}$ & $\begin{array}{l}6 / 60 \\
6 / 36 \\
6 / 9 \\
6 / 9 \\
6 / 24 \\
6 / 60 \\
6 / 18 \\
6 / 18 \\
6 / 60 \\
6 / 9 \\
<3 / 60 \\
<3 / 60 \\
6 / 12 \\
6 / 18 \\
6 / 6 \\
6 / 12 \\
6 / 9 \\
6 / 9 \\
6 / 6 \\
6 / 6 \\
6 / 6 \\
6 / 5 \\
6 / 9 \\
6 / 5 \\
6 / 6 \\
6 / 9 \\
6 / 6 \\
6 / 9 \\
6 / 6 \\
6 / 6\end{array}$ & $\begin{array}{l}6 / 60 \\
6 / 36 \\
6 / 9 \\
6 / 12 \\
6 / 36 \\
6 / 60 \\
6 / 12 \\
6 / 9 \\
6 / 60 \\
6 / 9 \\
<3 / 60 \\
6 / 6 \\
6 / 12 \\
6 / 9 \\
6 / 6 \\
6 / 9 \\
6 / 9 \\
6 / 5 \\
6 / 9 \\
6 / 6 \\
6 / 6 \\
6 / 5 \\
6 / 9 \\
6 / 6 \\
6 / 6 \\
6 / 9 \\
6 / 6 \\
6 / 6 \\
6 / 6 \\
6 / 6\end{array}$ & $\begin{array}{l}\text { PSC } \\
\text { PSC } \\
\text { None } \\
\text { PSC } \\
\text { None } \\
\text { PSC, CO } \\
\text { PSC } \\
\text { PSC } \\
\text { PSC } \\
\text { PSC } \\
\text { PSC } \\
\text { None } \\
\text { PSC } \\
\text { PSC } \\
\text { None } \\
\text { None } \\
\text { None } \\
\text { None } \\
\text { None } \\
\text { None } \\
\text { None } \\
\text { None } \\
\text { CO } \\
\text { None } \\
\text { None } \\
\text { CO } \\
\text { None } \\
\text { None } \\
\text { None } \\
\text { None }\end{array}$ & $\begin{array}{l}\text { MA, PEA, BS } 360^{\circ} \\
\text { MA, PEA, BS } 360^{\circ} \\
\text { PEA, BS, BS } 360^{\circ} \\
\text { PEA, BS } 360^{\circ} \\
\text { PEA, BS } 360^{\circ} \\
\text { PEA, BS } 360^{\circ} \\
\text { PEA, BS } 360^{\circ} \\
\text { MO, PEA, BS } 360^{\circ} \\
\text { MO, PEA, BS } 360^{\circ} \\
\text { PEA, BS } 360^{\circ} \\
\text { MA, PEA, BS } 360^{\circ} \\
\text { ONH, PEA, BS } 360^{\circ} \\
\text { MO, BS } 360^{\circ} \\
\text { PEA, BS } 360^{\circ} \\
\text { PEA, BS } 360^{\circ} \\
\text { MO, PEA, BS } 360^{\circ} \\
\text { PEA, BS } 360^{\circ} \\
\text { MO, BS } 360^{\circ} \\
\text { Normal } \\
\text { Normal } \\
\text { Normal } \\
\text { Normal } \\
\text { Normal } \\
\text { Normal } \\
\text { Normal } \\
\text { Normal } \\
\text { Normal } \\
\text { Normal } \\
\text { Normal } \\
\text { Normal }\end{array}$ \\
\hline
\end{tabular}

$3=$ Pedigree fig 1A, 4=pedigree Fig 1B. $s=$ Symptomatic, $d=$ disease haplotype carrier. PSC $=$ posterior subcapsular lens opacities, $C O=$ cortical lens opacities, $P E A=$ retinal pigment epithelial atrophy, $\mathrm{BS}=$ bone spicule retinal pigmentation, $\mathrm{MO}=$ macular oedema, $\mathrm{MA}=$ macular atrophy, ${ }^{\star}=$ reduced acuity owing to optic nerve head hypoplasia $(\mathrm{ONH})$ urelated to retinitis pigmentosa.

haplotype but only 37 (31\%) were symptomatic.

Seventeen symptomatic patients had eight $(47 \%)$ symptomatic and nine $(53 \%)$ disease haplotype carrier children. This compared with 12 asymptomatic disease haplotype carrier patients who had $19(76 \%)$ symptomatic and six (24\%) disease haplotype carrier children. The difference between the percentages of symptomatic children born to symptomatic and asymptomatic disease haplotype carrier parents was not statistically significant $\left(\chi^{2}=3.7, \mathrm{p}=0.05\right)$. Of the 27 symptomatic individuals whose parents were also included in generations III-V of pedigree 3 and II-IV of pedigree 4,17 had a male parent carrying the disease gene and 10 a female parent. Of 15 asymptomatic disease haplotype carriers with parents included in these generations 10 had a

Table 2 Dark adapted static sensitivities. Loss relative to lower normal limit

\begin{tabular}{|c|c|c|c|c|c|c|c|}
\hline \multirow[b]{3}{*}{ Patient } & \multirow{3}{*}{$\begin{array}{l}\text { Genetic } \\
\text { status }\end{array}$} & \multicolumn{6}{|c|}{ Dark adapted sensitivity loss (dB) } \\
\hline & & \multicolumn{3}{|c|}{ Blue stimulus } & \multicolumn{3}{|c|}{ Red stimulus } \\
\hline & & $3^{\circ}$ & $9^{\circ}$ & $27^{\circ}$ & $3^{\circ}$ & $9^{\circ}$ & $27^{\circ}$ \\
\hline 3-IV-15 & $\mathbf{s}$ & 28 & 31 & 31 & 22 & 26 & 26 \\
\hline $3-V-2$ & $\mathrm{~s}$ & 6 & 31 & 31 & 7 & 26 & 26 \\
\hline $3-V-5$ & $\mathrm{~s}$ & 27 & 31 & 31 & 15 & 26 & 26 \\
\hline $3-V-6$ & s & 28 & 31 & 31 & 26 & 26 & 26 \\
\hline 4-III-15 & $s$ & 31 & 31 & 31 & 16 & 26 & 26 \\
\hline $4-I V-11$ & s & 15 & 31 & 31 & 4 & 22 & 26 \\
\hline 4-IV-29 & s & 4 & 10 & 31 & 6 & 22 & 26 \\
\hline 4-IV-38 & $\mathrm{s}$ & 23 & 31 & 31 & 13 & 26 & 26 \\
\hline 3-IV-5 & d & 2 & 1 & 0 & 0 & 0 & 0 \\
\hline $3-I V-6$ & d & 0 & 0 & 0 & 0 & 0 & 0 \\
\hline $3-\mathrm{V}-13$ & d & 0 & 0 & 0 & 0 & 0 & 0 \\
\hline $3-V-16$ & $\mathrm{~d}$ & 0 & 0 & 0 & 0 & 0 & 0 \\
\hline 4-III-5 & d & 2 & 1 & 2 & 0 & 0 & 0 \\
\hline 4 -III-25 & $\mathrm{d}$ & 2 & 1 & $\overline{1}$ & 0 & 0 & 0 \\
\hline 4 -III-27 & $\mathrm{d}$ & 6 & 5 & 2 & 2 & 0 & 1 \\
\hline 4 -III-28 & $\mathrm{d}$ & 0 & 0 & 0 & 0 & 0 & 0 \\
\hline $4-I V-40$ & $\mathrm{~d}$ & 2 & 0 & 0 & 0 & 0 & 0 \\
\hline
\end{tabular}

Normal sensitivity ranges, blue $=31-50 \mathrm{~dB}, \mathrm{red}=26-37 \mathrm{~dB}$.

$\mathrm{s}=$ Symptomatic, $\mathrm{d}=$ disease-haplotype carrier. male parent carrying the disease gene and five a female parent. Therefore the sex of the parent carrying the disease gene did not seem to influence the likelihood that a child with the disease gene would be symptomatic.

The results of clinical examinations are presented in Table 1 . No individual identified as a disease haplotype carrier reported nightblindness in contrast with all symptomatic individuals, who reported nyctalopia by their mid teens. Typical fundus features of extensive peripheral retinal degeneration were seen in even the youngest examined symptomatic patient (24 years) with macular atrophy, oedema, and secondary cataract formation in older symptomatic individuals. Normal visual acuities and fundus examinations were recorded for even the oldest asymptomatic disease haplotype carrier (75 years). No systemic abnormality was identified as segregating with eye disease.

All symptomatic individuals assessed (24-61 years of age) had elevated dark adapted threshold sensitivities for the whole $30^{\circ}$ field tested with matching areas of rod and cone functional deficit (Table 2). Relative preservation of a central island of vision was evident in younger symptomatic individuals extending to approximately $9^{\circ}$ around fixation. In middle age this island was $<3^{\circ}$. In contrast, minimal threshold elevations were detected in the central $30^{\circ}$ of asymptomatic disease haplotype carriers (within $7 \mathrm{~dB}$ of the normal limit). Abnormal dark adaptometry results were obtained from all symptomatic patients tested with elevation of prebleach thresholds and elevated final thresholds (Table 3). Prebleach threshold elevation above $50 \mathrm{~dB}$ precluded dark adaptometry in symptomatic individuals over 52 years of age. All symptomless disease haplotype carrier individuals gave responses within $5 \mathrm{~dB}$ of normal mean values.

Electroretinographic responses were not detectable (that is, $<5 \mathrm{mV}$ ) in symptomatic individuals over 30 years of age. Significantly reduced electro-oculographic responses and ERG changes indicative of a severe rod-cone type photoreceptor deficit were seen in all younger symptomatic individuals (Table 4). Minor abnormalities in scotopic responses (within $34 \mathrm{mV}$ of the lower normal limit with normal implicit times) were also evident in two asymptomatic disease haplotype carrier patients (4-V-16, 24 years and 4-IV-5, 57 years). Dramatic differences were therefore seen in the results of field analysis and electrical responses of the youngest symptomatic patients in comparison with those from even the oldest disease haplotype carriers. These differences were not attributable to age.

\section{Discussion}

Matching areas of both rod and cone functional loss classify the phenotype seen in these families as R type (regional, type II), which contrasts with the widespread reduction in rod sensitivity with relative sparing of cone function seen in D type (diffuse, type I) disease. ${ }^{22} 23$ Some rhodopsin mutations appear to cause D type 
Table 3 Dark adaptometry

\begin{tabular}{|c|c|c|c|c|c|c|}
\hline Patient & & $\begin{array}{l}\text { Genetic } \\
\text { status }\end{array}$ & $\begin{array}{l}\text { Dark adapted } \\
\text { rod prebleach } \\
\text { threshold, } \\
\text { elevation }(d B)\end{array}$ & $\begin{array}{l}\text { Time to } \\
\text { conelrod } \\
\text { break } \\
\text { (minutes) }\end{array}$ & $\begin{array}{l}\text { Time to } \\
\text { prebleach } \\
\text { threshold } \\
\text { (minutes) }\end{array}$ & Dark adaption curve profile \\
\hline Normal & & & 0 & $9-11$ & $30-45$ & \\
\hline $3-V-2$ & $\begin{array}{l}\mathbf{x} \\
\mathbf{y}\end{array}$ & s & $\begin{array}{l}20 \\
30\end{array}$ & $\begin{array}{r}7 \\
12\end{array}$ & $\begin{array}{l}>45 \\
>45\end{array}$ & $\begin{array}{l}\text { Elevated final threshold } \\
\text { relative to prebleach value }\end{array}$ \\
\hline 4-IV-29 & $\begin{array}{l}x \\
y\end{array}$ & s & $\begin{array}{l}22 \\
40\end{array}$ & $\begin{array}{r}6 \\
13\end{array}$ & $\begin{array}{l}>45 \\
>45\end{array}$ & $\begin{array}{l}\text { Elevated final threshold } \\
\text { relative to prebleach value }\end{array}$ \\
\hline 4-III-25 & $\mathrm{x}$ & $\mathrm{d}$ & $\begin{array}{l}8 \\
9\end{array}$ & $\begin{array}{l}9 \\
9\end{array}$ & $\begin{array}{l}35 \\
35\end{array}$ & Normal \\
\hline 4-III-5 & $\mathrm{x}$ & d & 10 & 12 & $\begin{array}{l}40 \\
40\end{array}$ & Normal \\
\hline 4-III-27 & $\mathrm{x}$ & d & 10 & $\begin{array}{l}6 \\
6\end{array}$ & $\begin{array}{l}42 \\
42\end{array}$ & Normal \\
\hline 4-III-28 & $\begin{array}{l}\mathbf{y} \\
\mathbf{x} \\
\mathrm{y}\end{array}$ & d & $\begin{array}{l}9 \\
9\end{array}$ & $\begin{array}{l}0 \\
9 \\
9\end{array}$ & $\begin{array}{l}42 \\
37 \\
37\end{array}$ & Normal \\
\hline
\end{tabular}

$\mathrm{s}=$ Symptomatic, $\mathrm{d}=$ disease-haplotype carrier, $\mathrm{x}=$ visual field locus $(3,3), \mathrm{y}=$ visual field locus $(9,9)$.

functional loss, ${ }^{24-26}$ and others an $\mathbf{R}$ type loss associated with an altitudinal distribution of visual field deficit unlike that seen here. ${ }^{1827-34}$ Regional functional loss has also been described with peripherin/RDS mutations although severity was consistently related to age..$^{35}$ Detailed phenotype descriptions for pedigrees linked to $7 q, 8 c e n$, and $17 p$ are as yet unpublished. A phenotype with variable expression and an $\mathbf{R}$ type pattern of deficit has been described for the dominant retinitis pigmentosa pedigree linked to chromosome $7 \mathrm{p} .{ }^{12}$ However, a graded disease severity has been reported with mild, moderate, and severely affected individuals. By extending the clinical study on the two families, the present study has identified a large number of haplotype carriers who on clinical examination and intensive investigation are essentially normal. This establishes the phenotype, $\mathrm{R}$ type functional deficit with bimodal expressivity, as a real phenomenon in two large families that may be a unique feature of the $19 \mathrm{q}$ locus, and allows analysis of segregation of disease in the pedigrees.

To explain this unusual phenotypic expression, another influence in addition to the underlying causative mutation mapping to $19 q$ is most probably operating. This is unlikely to be environmental since such an effect would be expected to be dose dependent, and produce a graded rather than the 'all or nothing' phenotype seen here. In addition, despite extensive research, environmental factors such as ambient lighting have not been proved to have a large influence on disease severity in retinitis pigmentosa. ${ }^{336} \mathrm{~A}$ number of genetic mechanisms have been associated with variable expression of disease phenotype. Anticipation describes disease severity related to increasing trinucleotide repeat expansion as seen in fragile $\mathrm{X}$ syndrome ${ }^{37}$ and myotonic dystrophy. ${ }^{38}$ Imprinting is often the basis for a phenotype influenced by sex of the carrier parent. ${ }^{39}$ Incomplete penetrance in certain retinoblastoma pedigrees has been attributed to mutations in gene promoter sequence ${ }^{40}$ or 'mild' germline mutations which reduce but do not eliminate tumour suppression protein function. ${ }^{41}$ Anticipation, with severity related to position in a pedigree was not seen in this study, and the sex of the disease gene carrying parent did not influence the likelihood of a disease gene carrier being symptomatic. Also, the mechanism seen in retinoblastoma would not explain the bimodal expressivity seen in this study since incomplete penetrance of the retinoblastoma phenotype is usually associated with a relatively severe 'second hit' null mutation in somatic cells. ${ }^{41}$ Such somatic cell mutations could not explain the panretinal disease seen in retinitis pigmentosa.

Digenic inheritance describes the association of germline mutations in different genes that result together in phenotype expression but cause minimal or no function deficit when inherited individually. ${ }^{42}$ In retinitis pigmentosa cases associated with digenic inheritance, the gene products (peripherin/RDS and ROM1) are structural proteins known to interrelate functionally at a cellular level. Such a mechanism may imply that disease status in a particular individual linked to gene mutation at the $19 \mathrm{q}$ locus would be determined by the presence of a second gene expressing a functionally related protein. This suggests that the $19 q$ mutation and another modulating gene may encode related structural proteins, ion transport channel subunits, or related membrane bound proteins. The protein products of these two mutations may also possibly be enzyme subunits. Mutations of enzyme coding genes conventionally result in recessive

Table 4 Electrodiagnostic results

\begin{tabular}{|c|c|c|c|c|c|c|c|c|c|c|c|c|}
\hline \multirow[b]{4}{*}{ Patient } & \multirow{4}{*}{$\begin{array}{l}\text { Age } \\
\text { (years) }\end{array}$} & \multirow{4}{*}{$\begin{array}{l}E O G \\
\%\end{array}$} & \multicolumn{10}{|c|}{ Electroretinography } \\
\hline & & & \multirow{2}{*}{\multicolumn{2}{|c|}{$\begin{array}{l}\text { Run } 7 \\
\text { b wave }\end{array}$}} & \multirow{2}{*}{\multicolumn{2}{|c|}{$\begin{array}{l}\text { Run } 18 \\
b \text { wave }\end{array}$}} & \multicolumn{4}{|c|}{ Run 20} & \multirow{2}{*}{\multicolumn{2}{|c|}{ Run 31}} \\
\hline & & & & & & & $a$ war & & $b$ war & & & \\
\hline & & & $a m p$ & $i m p$ & $a m p$ & $i m p$ & $a m p$ & $i m p$ & $a m p$ & $i m p$ & $a m p$ & $i m p$ \\
\hline $\begin{array}{l}\text { 3-V-2 (s) } \\
4-I V-1(\mathrm{~s}) \\
4-I V-29(\mathrm{~s}) \\
4-I V-43(\mathrm{~s}) \\
3-I V-5(d) \\
3-V-13(\mathrm{~d}) \\
3-V-16 \text { (d) } \\
4-I I I-25(d) \\
4-I I I-27(d) \\
4-I V-9 \text { (d) } \\
\text { Normal mean } \\
\text { Normal limits }\end{array}$ & $\begin{array}{l}24 \\
26 \\
25 \\
28 \\
57 \\
33 \\
24 \\
25 \\
57 \\
26\end{array}$ & $\begin{array}{l}100 / 110 \\
137 / 135 \\
100 / 100 \\
195 / 210 \\
\\
141 / 161 \\
370 / 335 \\
200 / 218\end{array}$ & $\begin{array}{r}0 \\
0 \\
0 \\
0 \\
45 \\
120 \\
55 \\
140 \\
160 \\
80 \\
199 \\
79\end{array}$ & $\begin{array}{r}- \\
- \\
- \\
\overline{-} \\
120 \\
100 \\
95 \\
90 \\
100 \\
106 \\
100 \\
126\end{array}$ & $\begin{array}{r}15 \\
30 \\
10 \\
16 \\
60 \\
60 \\
60 \\
120 \\
200 \\
40 \\
153 \\
59\end{array}$ & $\begin{array}{l}50 \\
50 \\
46 \\
42 \\
50 \\
42 \\
48 \\
46 \\
44 \\
20 \\
47 \\
57\end{array}$ & $\begin{array}{r}30 \\
30 \\
7 \\
6 \\
50 \\
120 \\
41 \\
80 \\
60 \\
41 \\
132 \\
41\end{array}$ & $\begin{array}{l}30 \\
30 \\
30 \\
20 \\
30 \\
15 \\
25 \\
23 \\
22 \\
25 \\
22 \\
25\end{array}$ & $\begin{array}{r}20 \\
30 \\
18 \\
18 \\
220 \\
280 \\
220 \\
270 \\
260 \\
200 \\
384 \\
208\end{array}$ & $\begin{array}{l}50 \\
50 \\
50 \\
48 \\
50 \\
45 \\
51 \\
45 \\
44 \\
40 \\
45 \\
49\end{array}$ & $\begin{array}{r}10 \\
5 \\
10 \\
10 \\
35 \\
30 \\
25 \\
25 \\
35 \\
20 \\
43 \\
10\end{array}$ & $\begin{array}{l}40 \\
42 \\
47 \\
32 \\
31 \\
30 \\
35 \\
30 \\
30 \\
32 \\
29 \\
32\end{array}$ \\
\hline
\end{tabular}

EOG=electro-oculogram. Electroretinogram run 7 (rod isolated), run 18 (cone dominant), run 20 (mixed photoreceptor), and run 31 (cone photoreceptor) correspond to a 'short protocol' regimen. ${ }^{19} \mathrm{amp}=$ Wave amplitude, imp =implicit time. Normal limits for electroretinographic responses refer to the normal mean -2 SD for wave amplitudes and the normal mean $+2 S D$ for implicit times. $s=$ Symptomatic, $d=$ disease haplotype carrier. 
disease, but this well established dogma is not incontrovertible since a mutation in the $\beta$ subunit of the enzyme phosphodiesterase has been associated with a dominant congenital stationary nightblindness. ${ }^{43}$ The large number of symptomatic individuals from symptomless disease haplotype carriers would suggest that the second proposed mutation, derived from the unrelated spouse, may be common in the general population. Since in itself this second mutation is not associated with disease it could be described as a gene polymorphism. However, it would be expected that if digenic inheritance explained the disease segregation in this study, then symptomatic individuals would be significantly more likely to have symptomatic children than disease haplotype carriers. This was not the case in these families since only $50 \%$ of children carrying the disease gene derived from symptomatic individuals were themselves symptomatic compared with $76 \%$ of children with the disease gene derived from a disease haplotype carrier parent. This finding may be explained if the second genetic influence in these families was in fact allelic to the $19 \mathrm{q}$ mutation. Such allelic mutations, modifying disease expression have been identified in Drosophila where the phenomenon is termed intragenic complementation. ${ }^{44}$ Also, an allelic, symptomless polymorphism of the spectrin gene, common in the population, has been implicated as modulating the severity of symptoms in humans with a primary spectrin mutation causing hereditary haemolytic anaemia. ${ }^{45}$ This hypothesis will easily be testable once the $19 q$ mutant gene is isolated.

Despite intensive work on cDNA libraries in many laboratories, to date no research worker has identified a retina specific gene on chromosome 19. However, techniques used to generate tissue specific libraries usually identify genes that give rise to larger amounts of protein. the $19 \mathrm{q}$ gene product, although important to cell function, may not be a large contributor to the protein content of retinal cells. ${ }^{46}$ Alternatively, the gene of interest may not be retina specific. Although no systemic disease was identified, the function of the defective gene may be compensated for in other tissues in a way not possible in the retina.

In the past genetic counselling of such families has been difficult since clinical examination and extensive investigation would not exclude the presence of the abnormal gene even in late life. Although, as expected, roughly $50 \%$ of at risk individuals had the disease haplotype the overall risk of being significantly visually handicapped during a working lifetime was only $31 \%$. In addition, 'minimal' disease in a parent did not imply an increased likelihood of 'minimal' disease in offspring. In these families accurate counselling is therefore dependent upon molecular genetic haplotype analysis.

1 Heckenlively JR. Retinitis pigmentosa. Philadelphia: JB Lippincott, 1988.

2 Bundey S, Crews SJ. A study of retinitis pigmentosa in the city of Birmingham. II. Clinical and genetic heterogeneity. f Med Genet 1984; 21 : 421-8. 3 Jay $M$. On the heredity of retinitis pigmentosa. $B r f$
Ophthalmol 1982; 66: 405-16.
4 Al-Maghtheh M, Gregory CY, Inglehearn CF, Hardcastle A, Bhattacharya SS. Rhodopsin mutations in autosomal dominant retinitis pigmentosa. Hum Mutat 1993; 2: 249-55.

5 Farrar GJ, Jordan SA, Kumar-Singh R, Inglehearn CF, Gal A, Gregory CY, et al. Extensive genetic heterogeneity in autosomal dominant retinitis pigmentosa. In: Hollyfield JG, Anderson RE, LaVail MM, ed. Retinal degeneration. Clinical and laboratory applications. New York: Plenum, 1994: 63-77.

6 Inglehearn CF, Carter SA, Keen TJ, Lindsey J, Stephenson AM, Bashir R, et al. A new locus for autosomal dominant retinitis pigmentosa on chromosome $7 \mathrm{p}$. Nature Genet 1993; 4: 51-3.

7 Jordan SA, Farrar GJ, Kenna P, Humphries MM, Sheils DM, Kumar Singh R, et al. Localization of an autosomal dominant retinitis pigmentosa gene to chromosome $7 \mathrm{q}$. Nature Genet 1993; 4: 54-8.

8 Blanton SH, Heckenlively JR, Cottingham AW, Friedman J, Sadler LA, Wagner M, et al. Linkage mapping of autosomal dominant retinitis pigmentosa (RP1) to the pericentric region of human chromosome 8. Genomics 1991 ; 11: 857-69.

9 Greenberg J, Goliath R, Beighton P, Ramesar R. A new locus for autosomal dominant retinitis pigmentosa on the short arm of chromosome 17. Hum Mol Genet 1994; 3 915-8.

10 Al-Maghtheh M, Inglehearn CF, Keen TJ, Evans K, Moore $\mathrm{AT}$, Jay $M$, et al. Identification of a sixth locus for autosomal dominant retinitis pigmentosa on chromosome 19 Hum Mol Genet 1994; 3: 351-4.

11 Weleber RG, Carr RE, Murphey WH, Sheffield VC, Stone EM. Phenotypic variation including retinitis pigmentosa, pattern dystrophy, and fundus flavimaculatus in a single family with a deletion of codon 153 or 154 of the peripherin/RDS gene. Arch Ophthalmol 1993; 111: peripheri

12 Moore AT, Fitzke F, Jay $M$, Arden GB, Inglehearn $C F$, Keen TJ, et al. Autosomal dominant retinitis pigmentosa with apparent incomplete penetrance: a clinical, electrophysiological, psychophysical and molecular genetic study. Br f Ophthalmol 1993; 77: 473-79.

13 Massof RW, Finklestein D. Rod sensitivity relative to cone sensitivity in retinitis pigmentosa. Invest Ophthalmol Vis Sci 1979; 18: 263-72.

14 Jacobson SG, Voigt WJ, Parel JM, Apathy PP, Nghiem Phu L, Myers SW, et al. Automated light- and dark-adapted $\mathrm{L}$, Myers SW, et al. Automated light- and dark-adapted perimetry for evaluating re

15 Chen JC, Fitzke FW, Pauleikhoff D, Bird AC. Functional loss in age-related Bruch's membrane change with choroidal perfusion defect. Invest Ophthalmol Vis Sci 1992 33: $334-40$.

16 Ernst W, Faulkner DJ, Hogg CR, Powell DJ, Arden GB. An automated static perimeter/adaptometer using light emitting diodes. Br F Ophthalmol 1983; 67: 431-42.

17 Steinmetz RL, Polkinghorne PC, Fitzke FW, Kemp CM, Bird AC. Abnormal dark adaptation and rhodopsin kinetics in Sorsby's fundus dystrophy. Invest Ophthalmol Vis Sci 19s in Sorsby's fund

18 Moore AT, Fitzke FW, Kemp CM, Arden GB, Keen TJ, Inglehearn CF, et al. Abnormal dark adaption kinetics in autosomal dominant sector retinitis pigmentosa due to rod opsin mutation. Br f Ophthalmol 1992; 76: 465-9.

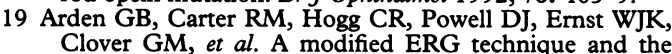
results obtained in $\mathrm{X}$-linked retinitis pigmentosa. $\mathrm{Br} f$ Ophthalmol 1981; 67: 419-30.

20 International Standardisation Committee. Standard for clinical electroretinography. Arch Ophthalmol 1989; 107: 816-9.

21 Arden GB, Barrada A, Kelsey JH. New clinical test of retinal function based upon the standing potential of the eye. Br F Ophthalmol 1962; 46: 449-67.

22 Massof RW, Finkelstein D. Two forms of autosomal dominant primary retinitis pigmentosa. Doc Ophthalmol 1979; 51: 289-346.

23 Lyness AL, Ernst WJK, Quinlan MP, Clover GM Arden GB, Carter RM, et al. A clinical, psychophysical and electroretinographic survey of patients with autosomal dominant retinitis pigmentosa. Br $\mathcal{F}$ Ophthalmol 1985; 69: 326-39.

24 Berson EL, Rosner B, Sandberg MA, Weigel-DiFranco C, Dryja TP. Ocular findings in patients with autosomal dominant retinitis pigmentosa and rhodopsin, proline347-leucine. Am f Ophthalmol 1991; 111: 614-23.

25 Jacobson SG, Kemp CM, Sung CH, Nathans J. Retinal function and rhodopsin levels in autosomal dominan retinitis pigmentosa with rhodopsin mutations. $A m \mathcal{F}$ Ophthalmol 1991; 112: 256-71.

26 Restagno G, Maghtheh $M$, Bhattacharya $S$, Ferrone $M$, Garnerone S, Samuelly R, et al. A large deletion at the $3^{\prime}$ end of the rhodopsin gene in an Italian family with a diffuse form of autosomal dominant retinitis pigmentosa. Hum Mol Genet 1993; 2: 207-8.

27 Kemp CM, Jacobson SG, Roman AJ, Sung CH, Nathans J. Abnormal rod dark adaption in autosomal dominant Abnormal rod dark adaption in autosomal dominant retinitis pigmentosa with proline-23-histidine rhod
mutation. Am $\mathcal{f}$ Ophthalmol 1992; 113: 165-74.

28 Fishman GA, Stone EM, Gilbert LD, Sheffield VC. Ocular findings associated with a rhodopsin gene codon 106 mutation. Arch Ophthalmol 1992; 110: 646-53.

29 Fishman GA, Vandenburgh K, Stone EM, Gilbert LD Alexander KR, Sheffield VC. Ocular findings associated with rhodopsin gene codon 267 and codon 190 mutations 
in dominant retinitis pigmentosa. Arch Ophthalmol 1992; 110: $1582-8$.

30 Fishman GA, Stone EM, Sheffield VC, Gilbert LD, Kimura AE. Ocular findings associated with rhodopsin gene codon 17 and codon 182 transition mutation in dominan retinitis pigmentosa. Arch Ophthalmol 1992; 110: 54-62.

31 Hayakawa M, Hotta Y, Imai Y, Fujiki K, Nakamura A Yanashima K, et al. Clinical features of autosomal dominant retinitis pigmentosa with rhodopsin gene codon 17 mutation and retinal neovascularization in a Japanese patient. Am f Ophthalmol 1993; 115: 168-73.

32 Kranich H, Bartkowski S, Denton MJ, Krey S, Dickinson P, Duvigneau C, et al. Autosomal dominant 'sector' retinitis pigmentosa due to a point mutation predicting an Asn-15Ser substitution of rhodopsin. Hum Mol Genet 1993; 2: 813-4.

33 Sullivan LJ, Makris GS, Dickenson P, Mulhall LEM, Forrest $S$, Cotton RGH, et al. A new codon 15 rhodopsin gene mutation in autosomal dominant retinitis pigmentosais associated with sectoral disease. Arch Ophthalmol 1993; 111: 1512-7.

34 Kim RY, Al-Maghtheh M, Fitzke FW, Arden GB, Jay M, Bhattacharya SS, et al. Dominant retinitis pigmentosa associated with two rhodopsin gene mutations. Arch Ophthalmol 1993; 111: 1518-24.

35 Wells J, Wroblewski J, Keen J, Inglehearn C, Jubb C, Eckstein A, et al. Mutations in the human retinal degeneration slow (RDS) gene can cause either retinitis pigmentosa or macular dystrophy. Nature Genet 1993; 3: 213-8.

36 Berson EL. Light deprivation and retinitis pigmentosa Vision Res 1980; 20: 1179-84

37 Richards RI, Holman K, Friend K, Kremer E, Hillen D,
Staples A, et al. Evidence of founder chromosomes in fragile X syndrome. Nature Genet 1992; 1: 257-60.

38 Tsilfidis RG. Correlation between CTG trinucleotide repeat length and frequency of severe congenital myotonic dystrophy. Nature Genet 1992; 1: 192-5.

39 Magenis RE, Toth-Fejel S, Allen LJ, Black M, Brown MG, Budden $S$, et al. Comparison of the $15 \mathrm{q}$ deletions in Prader-Willi and Angelman syndromes: specific regions, extent of deletions, parental origin, and clinical consequences. Am F Med Genet 1990; 35: 333-49.

40 Sakai T, Ohtani N, McGee L, Robbins PD, Dryja TP. Oncogenic germ-line mutations in SP1 and ATF sites in the human retinoblastoma gene. Nature 1991; 353: 83-6.

41 Dryia TP, Rapaport J, McGee TL, Nork TM, Schwartz TL. Molecular etiology of flow penetrance retinoblastoma in two pedigrees. Am 7 Hum Genet 1993; 52: 1122-8.

42 Kajiwara K, Berson EL, Dryja TP. Digenic retinitis pigmentosa due to mutations at pherin/RDS and ROM1 loci. Science 1994; 264: 1604-8.

$43 \mathrm{Gal} \mathrm{A}$, Orth U, Baehr W, Schwinger E, Rosenberg T. Heterozygous missense mutation in the rod cGMP phosphodiesterase b-subunit gene in autosomal dominant stationary night blindness. Nature Genet 1994; 7: 64-8.

44 Suzuki DT, Griffiths AJF, Lewontin RC. An introduction to genetic analysis. San Francisco: WH Freeman, 1981.

45 Gratzer W. Silence speaks in spectrin. Nature 1994; 372: 620-1.

46 Bowes-Rickman C, Rapaport A, Danciger M, Cavallo C, Kozak C, Farber DB. Cloning and characterization of novel photoreceptor-specific cDNAs. Invest Ophthalmol Vis Sci 1994; 35 (suppl): 1833. 